\title{
Breast Cancer cN2 TNM Finding v7
}

National Cancer Institute

\section{Source}

National Cancer Institute. Breast Cancer cN2 TNM Finding v7. NCI Thesaurus. Code C88368.

Breast cancer with metastases in ipsilateral level I, II axillary lymph nodes that are clinically fixed or matted; or in clinically detected ipsilateral internal mammary nodes in the absence of clinically evident axillary lymph node metastases. "Clinically detected" is defined as detected by imaging studies (excluding lymphoscintigraphy) or by clinical examination and having characteristics highly suspicious for malignancy or a presumed pathologic macrometastasis based on fine needle aspiration biopsy with cytologic examination. (from AJCC 7th Ed.) 